\title{
Comparison of reproductive organs structure in various genotypes of Phaseolus vulgaris grown under the same conditions in Mersin, Turkey
}

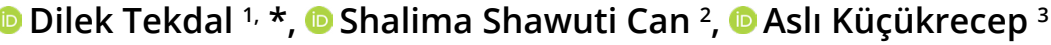 \\ 1 Department of Biotechnology, Faculty of Science and Letters, Mersin University, 33110 Mersin, Turkey; * dilektekdal@mersin.edu.tr \\ 2 Department of Physiology, Faculty of Medicine, Istanbul University, 34452 Istanbul, Turkey \\ ${ }^{3}$ Department of Biotechnology, Institute of Science, Mersin University, 33110 Mersin, Turkey
}

Received: 02.07.2021 | Accepted: 06.08.2021 | Published online: 25.08.2021

\begin{abstract}
The common bean (Phaseolus vulgaris) is a plant having hermaphroditic flowers, which are self-fertilizing. Common bean is a important commercial crop and one of Turkey's most valuable grain legumes for human consumption. Genetic variation exists within and between bean populations. These variations can have an impact on the plants morphology, including reproductive organs. Variations in size and length of reproductive organs may cause different cell numbers and various fertilization successes. In this study, the response of four determinate common bean genotypes (Akman, Bitlis 117, Göksun, and Karacaşehir) to reproductive organ structure was studied. Plants were grown at $21 / 16^{\circ} \mathrm{C}$ (day/night) and $12 \mathrm{~h}$ photoperiod in a greenhouse in Mersin, Turkey. Besides focusing mainly on pollen development, fertilization success factors such as pod and seed set were also assessed. Pod and seed set were evaluated numerically for each genotype. For pollen morphology, flower buds of the equal growth stage of all four bean genotypes were collected, and these samples were analyzed by scanning electron microscopy. The species have distinct morphological characteristics concerning pollen size, ornamentation patterns of the exine, and endoaperture type. It is also crucial to examine pollen dispersion in the pollinated flowers, as it may influence reproductive success. However, pollen wall architecture was similar in all genotypes tested. Despite general morphological similarity, differences in pollen viability and pod and seed number were observed. Although Akman genotype had the largest flowers, the Karacaşehir genotype was found to be the most productive one. The findings presented here can be helpful for researchers studying bean breeding and those investigating the morphological variation in different Phaseolus genotypes.
\end{abstract}

Keywords: Phaseolus vulgaris, common bean, pollen, reproduction

Authors' contributions: Conceived and designed the experiments: D. Tekdal. Performed the experiments: D. Tekdal, S. Shawuti Can, and A. Küçükrecep. Supervised the study: D. Tekdal. Wrote the paper: D. Tekdal. Critically revised the manuscript: D. Tekdal, S. Shawuti Can, and A. Küçükrecep.

Funding: This research was supported in part by Project No. 1190003 from the Scientific and Technological Research Council of Turkey (TÜBITAK).

Competing Interests: The authors declared no conflict of interest.

\section{Introduction}

Fabaceae Lindl. (Leguminosae Juss.) is one the most prominent family of flowering plants, consisting of 630 genera and about
20,000 species (Croser et al., 2006; da Luz et al., 2013; Chase et al., 2016). It is the world's third-largest widely distributed angiosperm family, second in agricultural 


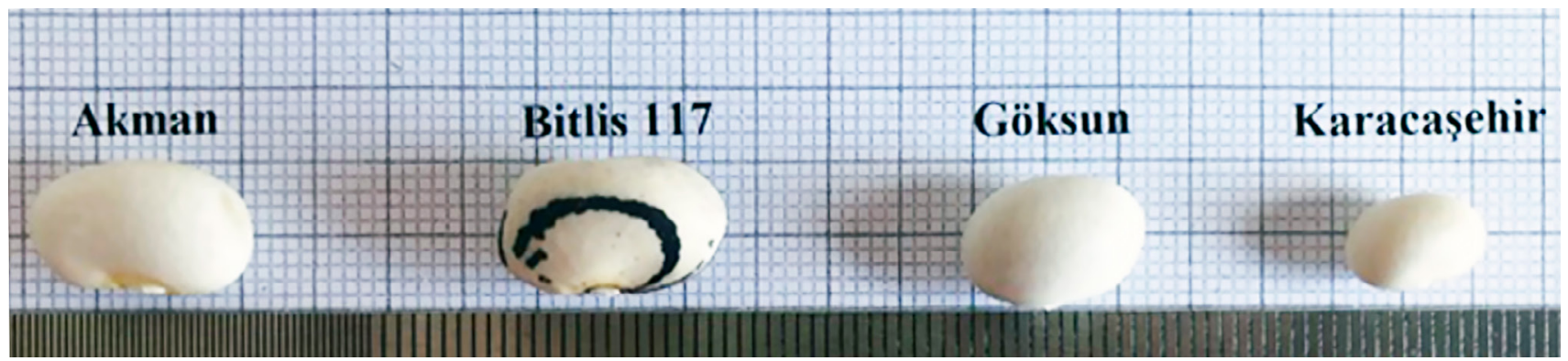

Figure 1. Seeds of investigated Phaseolus vulgaris genotypes.

economic significance (da Luz et al., 2013). Fabaceae is divided into six subfamilies: Cercidoideae LPWG, Detarioideae Burmeist., Duparquetioideae LPWG, Dialioideae LPWG, Papilionoideae DC., and Caesalpinioideae DC. (Azani et al., 2017). Fabaceae, in general, have floral features that lead to a wide range of pollination mechanisms (Stirton, 1981). Although the papilionaceous flowers have a huge impact on pollen economy, the pollen morphology and development has been studied very little in this family.

Common bean (Phaseolus vulgaris L.) belongs to the tribe Phaseoleae DC., one of the Papilionoid clades (Croser et al., 2006). The common bean is specific in its morphology, root nodules, and pollination mechanism. These are diploid $(2 n=22)$, herbaceous, autogamous annual plant, self-pollinating with a limited percentage of out-crossing.

The present work compares the morphology of certain reproductive structures in four P. vulgaris genotypes. The main goal of the study was to gain knowledge of pollen architecture, which provides indirect information about the breeding system. In addition, it was also targeted to understand the floral and reproductive biology of selected P. vulgaris genotypes, which could optimize their management and restoration.

\section{Material and methods}

\section{Plant material}

This research used seeds of four genotypes of P. vulgaris (i.e., Akman, Bitlis 117, Göksun, and Karacassehir) (Fig. 1). The greenhouse experiments were conducted in Mersin, Turkey. Plants were grown individually in plastic pots and watered keeping adequate soil moisture. Plants were grown at the temperature of $21 / 16^{\circ} \mathrm{C}$ (day/night) with roughly $150 \mu \mathrm{E} \mathrm{m}^{-2} \mathrm{~s}^{-1}$ light intensity, and a $12 \mathrm{~h}$ photoperiod. The relative humidity was preserved below $80 \%$ by controlling the air exchange. Each experiment was performed in a fully randomized design with triplicates.

Seed germination in all tested varieties happened one week later, and plants have been grown for two months to achieve the required developmental stage of flower buds (Fig. 2). After that, the flower buds were harvested for further analysis.

\section{SEM analysis}

Flower buds were collected in May-June 2020. Anthers were dissected under a stereomicroscope (Olympus SZ61, Japan) and air-dried for scanning electron microscopy (SEM). The anther of each genotype was dried under a vacuum chamber for $48 \mathrm{~h}$. The samples were gold-coated before being placed in the SEM vacuum chamber. The surface topography of the pollen grains and grain size distributions were observed by SEM with an energy dispersive $x$-ray spectrometer (EDS, FEG-SEM Leo Supra 35, and Bruker XFlash). For stomata observation, flowers were collected and fixed in $70 \%$ ethanol immediately at the greenhouse, taken through a dehydration series $(70 \%$ ethanol - $80 \%$ ethanol - $96 \%$ ethanol - $96 \%$ ethanol:acetone (1:1) acetone), and observed under SEM. Stomata were observed and photographed for each genotype.

\section{Pollen viability, pollen fertility, and flower morphology}

To examine the morphology of the anthers, flower buds were collected during the blooming season. Three flowers from different 

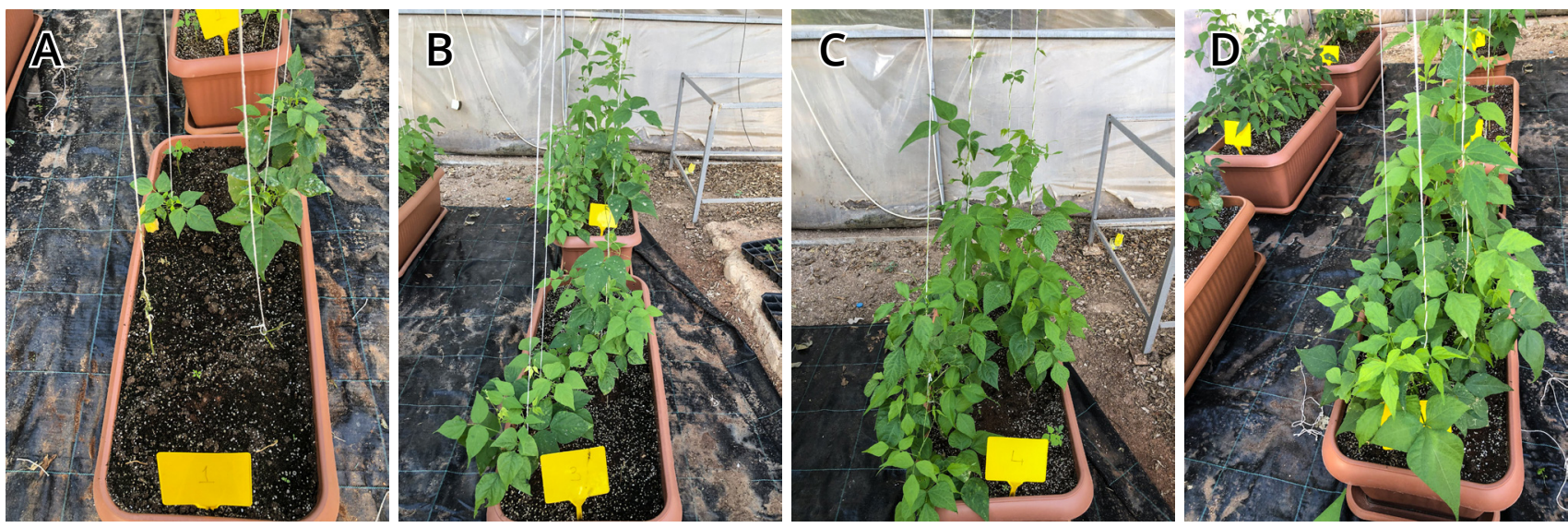

Figure 2. One-month-old Phaseolus vulgaris plants grown in the greenhouse: A - Akman; B - Bitlis 117; C - Göksun; D - Karacaşehir.
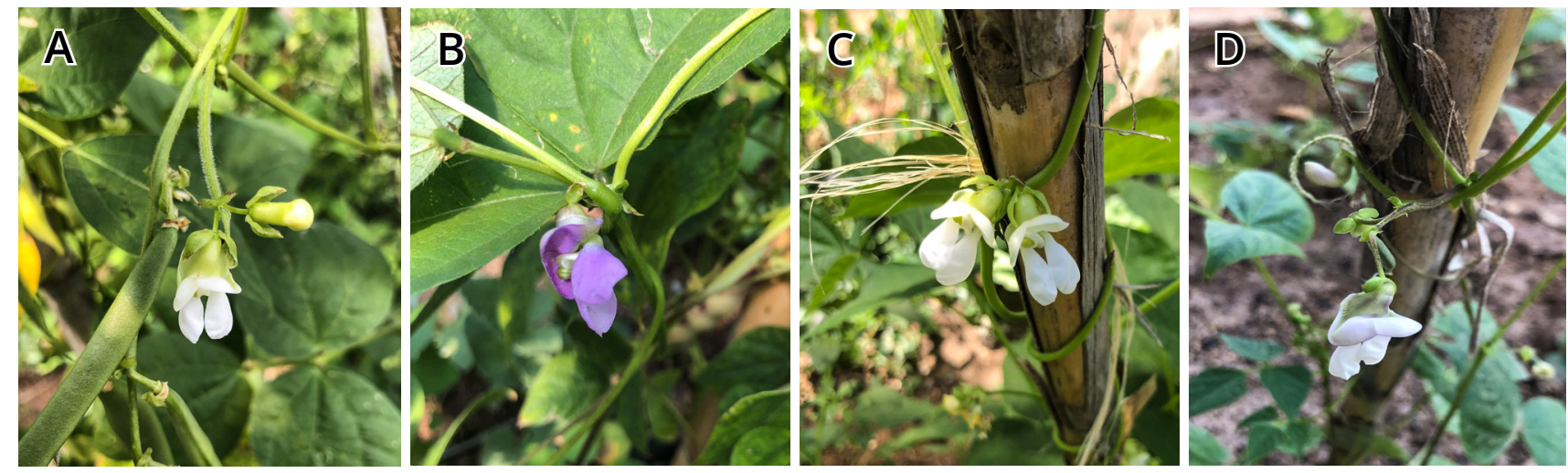

Figure 3. One-month-old Phaseolus vulgaris plants grown in the greenhouse: A - Akman; B - Bitlis 117; C - Göksun; D - Karacaşehir.

branches were examined for pollen fertility; as a result - at least 150 pollen grains were counted per each flower.

Pollen was collected from each genotype during anthesis, distributed on a glass slide with a drop of acetocarmine, and covered with a coverslip. The pollen grains were observed through a fluorescent microscope (Olympus BX51, Japan) and subsequently classified as fertile or infertile.

Fifty fruits were collected at the fruiting stage from each plant to determine seed production. A total number of fully formed seeds and aborted ovules were counted. The ratio of the number of seeds to the number of ovules per pod (\%) was calculated as an indicator of reproductive efficiency.

The perianth color of each genotype was determined during the visual examination of the fresh material.

\section{Results and discussion}

\section{Morphological observations}

The appearance of Fabaceae flowers to the insects is complex, with the main variations between the genera and the species depending on the wing characteristics (López et al., 1999). In Mersin (Turkey) P. vulgaris usually blooms in April and May. Its flowering lasts for about 20 days on an individual plant. The petals of these plants are typically whitish, and less frequently, they can be violet-purple (Fig. 3). Some petals reflect UV radiation due to pigment variation or presence of reflective hairs.

The most considerable floral lengths were found in the genotypes Akman $(13.0 \mathrm{~mm})$ and Göksun $(14.0 \mathrm{~mm})$, and the smallest ones - in the genotypes Bitlis $117(7.5 \mathrm{~mm})$ and Karacaşehir (4.5 mm). López et al. (1999) stated that floral size is correlated directly with the number of ovules. However, in our study, Karacaşehir genotype having the shortest 

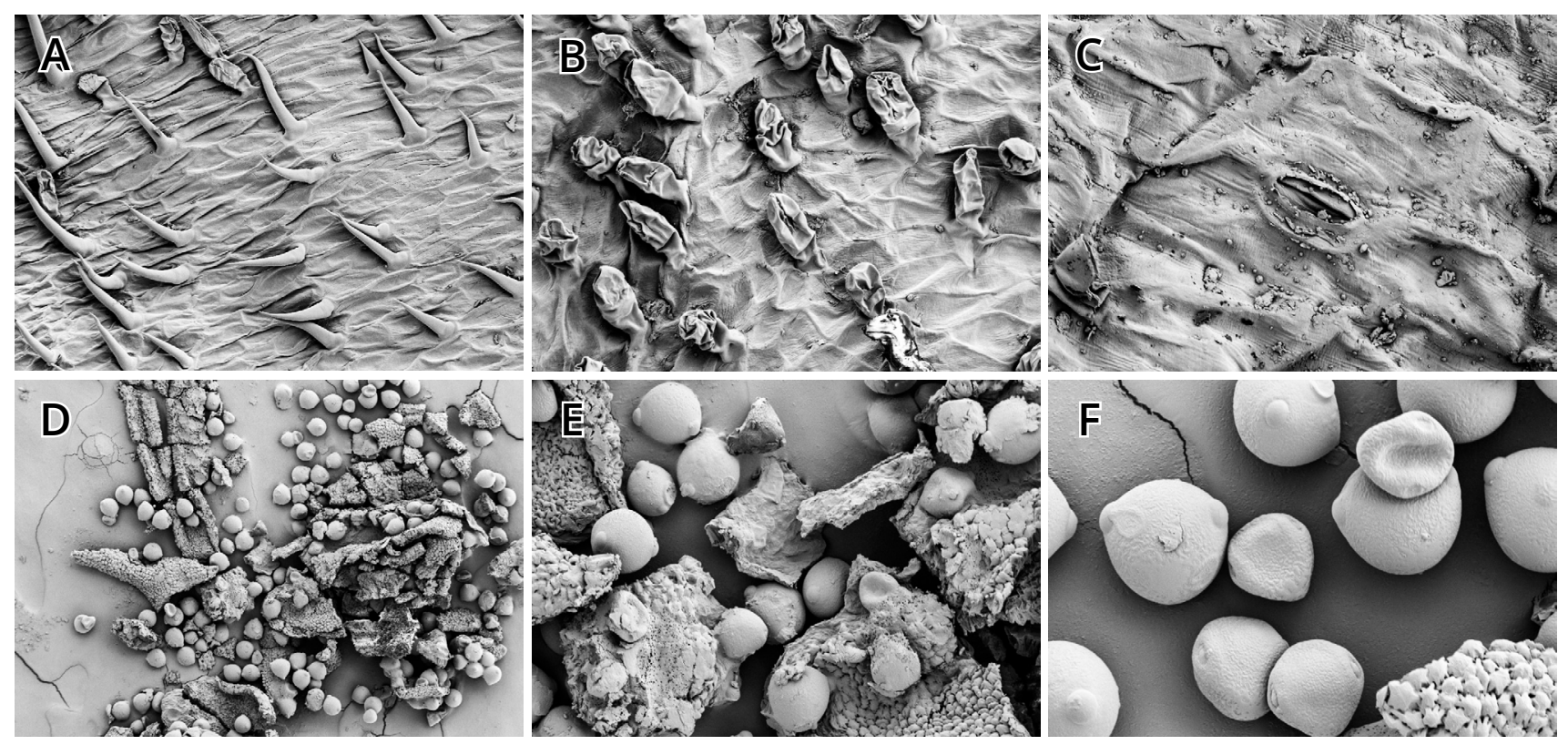

Figure 4. Generative structures of Akman genotype of Phaseolus vulgaris (SEM). A - hairs on the anther surface $(\times 500)$; B - anther epidermis $(\times 1 \mathrm{~K})$; C - stomata on the bottom of the calyx $(\times 2 \mathrm{~K})$; D-F - pollen grains at different magnifications $(\times 300, \times 1 \mathrm{~K}$, and $\times 2 \mathrm{~K}$, respectively).
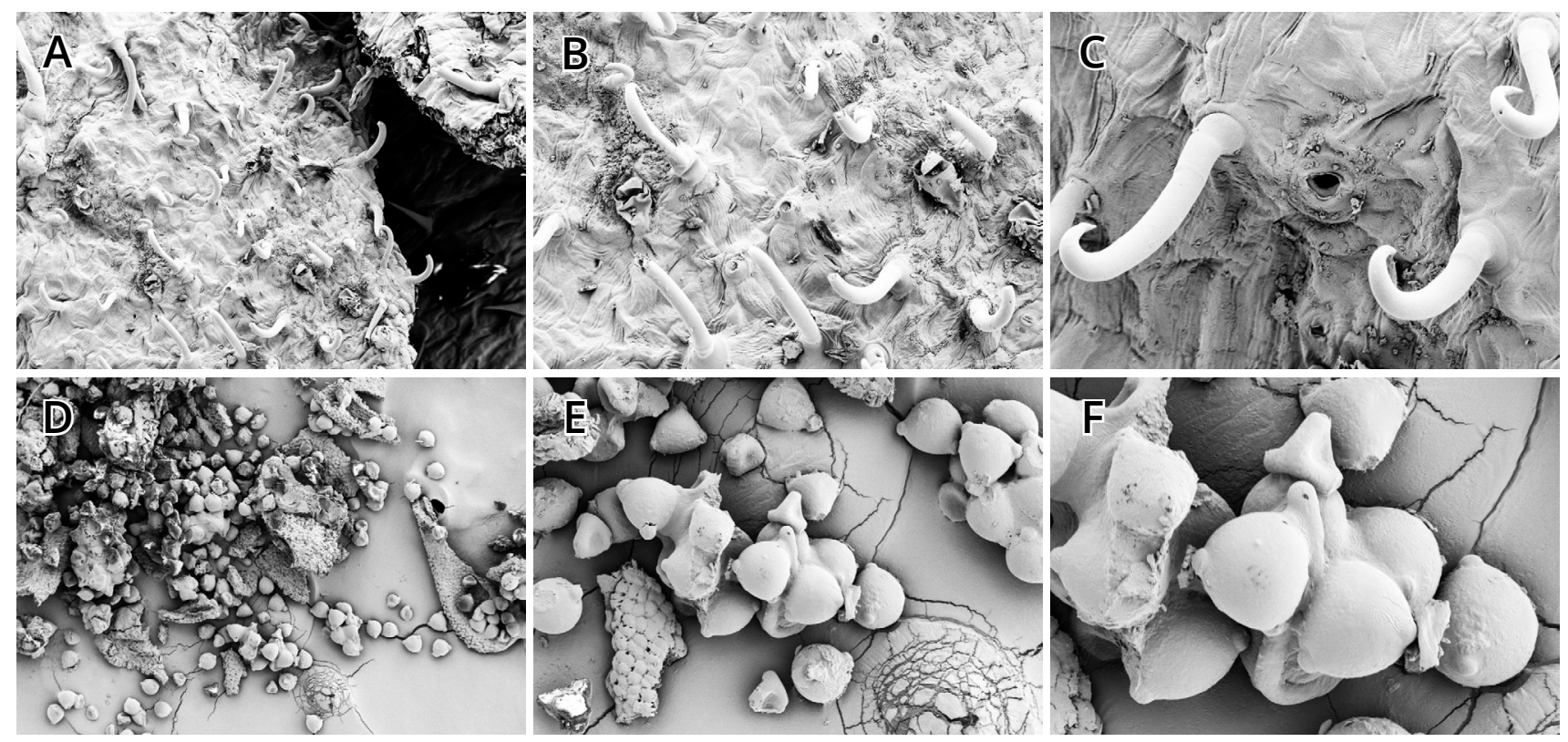

Figure 5. Generative structures of Bitlis 117 genotype of Phaseolus vulgaris (SEM). A - anther epidermis $(\times 500)$; B - hairs on the anther surface $(\times 1 \mathrm{~K}) ; \mathrm{C}$ - stomata on the bottom of the calyx $(\times 2 \mathrm{~K})$; D-F - pollen grains at different magnifications $(\times 300, \times 1 \mathrm{~K}$, and $\times 2 \mathrm{~K}$, respectively).

flower length was the most productive with six ovules. Akman genotype was in second place with five ovules. The least productive genotypes were Bitlis 117 and Göksun with four ovules per pod.

\section{SEM analysis and anther morphology}

The surface morphologies of each sample obtained from SEM studies are illustrated in
Figs. 4-7. Anthers of the studied genotypes are uniform. They have comparable epidermal characteristics. Some stomata have been detected on the dorsal end of the conjunctive. There are staminal filaments, but they are devoid of stomata. Pollen grains are mediumsized, isopolar, circular, and polar-view. The pollen grains' exine is resistant to strong chemicals, allowing long-term preservation 


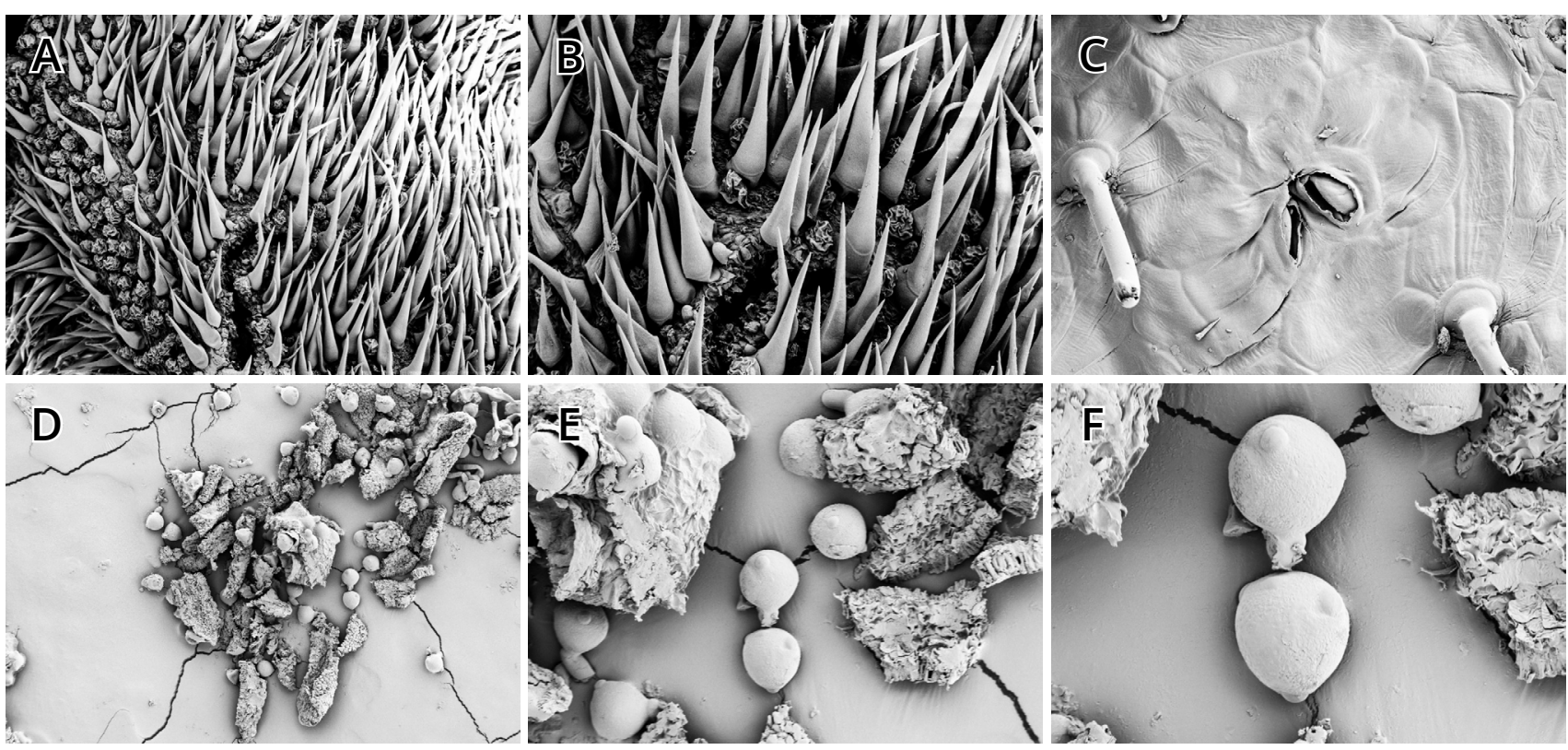

Figure 6. Generative structures of Göksun genotype of Phaseolus vulgaris (SEM). A - anther epidermis ( $\times 500)$; B - hairs on the anther surface $(\times 1 \mathrm{~K}) ; \mathrm{C}$ - stomata on the bottom of the calyx $(\times 2 \mathrm{~K})$; D-F - pollen grains at different magnifications $(\times 300, \times 1 \mathrm{~K}$, and $\times 2 \mathrm{~K}$, respectively).
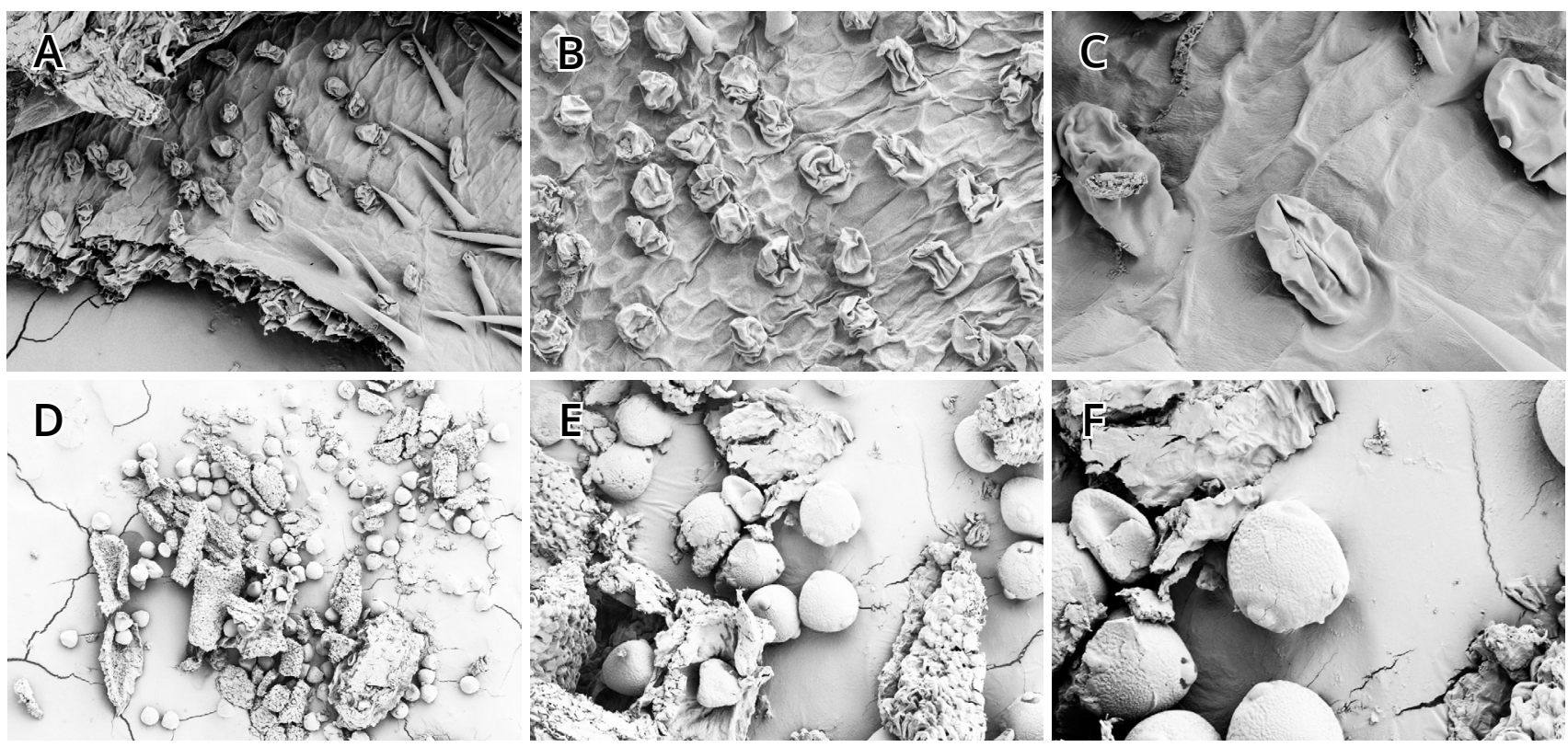

Figure 7. Generative structures of Karacaşehir genotype of Phaseolus vulgaris (SEM). A - anther epidermis $(\times 500) ; \mathrm{B}$ - hairs on the anther surface $(\times 1 \mathrm{~K}) ; \mathrm{C}$ - stomata on the bottom of the calyx $(\times 2 \mathrm{~K})$; D-F - pollen grains at different magnifications $(\times 300, \times 1 \mathrm{~K}$, and $\times 2 \mathrm{~K}$, respectively).

in an airless environment (Erdtman, 1969). At the same time, male sterility is often caused by irregular exine creation (Heslop-Harrison, 1972; Radice et al., 2008).

The anthers of some Fabaceae have tufts of hairs that can aid pollen transmission to pollinators or serve as a filter to keep pollen grains apart from their stigmas (Schrire, 1989). Phaseolus is considered a self-compatible genus since out-crossing rates are meager and depend on the season, pollinator density, and genotype. Graham \& Ranalli (1997) demonstrated that $P$. vulgaris pollen could fertilize the ovules of the same flower. In our research, all four genotypes were able to produce seeds successfully. Pollen grains with light staining, abnormal morphology, and decreased or nonexistent protoplasm were 
deemed sterile, but those with complete cell walls and intensely stained protoplasm were considered fertile. High seed production in all genotypes indicated that pollen was highly fertile.

It was reported that pollen fertility decreased under high temperatures and pollen was more heat-sensitive than the ovules (Nakano \& Asada, 1981). During hightemperature conditions, the tapetum, which is the innermost layer of the anther, may degenerate, and this may cause structural abnormalities of microspores (Suzuki et al., 2001). In our study, we investigated anther tissues under optimum conditions. Therefore, degenerated pollen grains were not observed.

\section{Conclusions}

Not so many surveys on anther structure of members of the Papilionoid clade have been available to date. No comprehensive observations on the anther structure and development of Akman, Bitlis 117, Göksun, and Karacaşehir genotypes of P. vulgaris have been performed to date. Here we present the results of the first detailed study on the structure of some generative organs of P. vulgaris. It is suggested that anther wall structure may affect pollen productivity and subsequently on seed set. Findings on the structure of the male organs of this species can be interesting for further breeding and seed productivity investigations.

\section{Acknowledgements}

This research was supported in part by Project No. 1190003 from the Scientific and Technological Research Council of Turkey (TÜBİTAK).

\section{References}

Azani, N., Babineau, M., Bailey, C., Banks, H., Barbosa, A. R., Pinto, R. B., Boatwright, J. S., Borges, L., Brown, G., Bruneau, A., Cândido, E., Cardoso, D., Chung, K., Clark, R., Conceição, A., Crisp, M., Cubas, P., Delgado-Salinas, A., Dexter, K. G. ... Zimmerman, E. (2017). A new subfamily classification of the leguminosae based on a taxonomically comprehensive phylogeny. Taxon, 66(1), 44-77. https://doi. org/10.12705/661.3

Chase, M. W., Christenhusz, M. J. M., Fay, M. F., Byng, J. W., Judd, W. S., Soltis, D. E., Mabberley, D. J., Sennikov, A. N., Soltis, P. S., \& Stevens, P. F. (2016). An update of the Angiosperm Phylogeny Group classification for the orders and families of flowering plants: APG IV. Botanical Journal of the Linnean Society, 181(1), 1-20. https://doi.org/10.1111/boj.12385

Croser, J. S., Lülsdorf, M. M., Davies, P. A., Clarke, H. J., Bayliss, K. L., Mallikarjuna, N., \& Siddique, K. H. M. (2006). Toward doubled haploid production in the Fabaceae: progress, constraints, and opportunities. Critical Reviews in Plant Sciences, 25(2), 139-157. https://doi. org/10.1080/07352680600563850

da Luz, C. F. P., Maki, E. S., Horák-Terra, I., VidalTorrado, P., \& Mendonça Filho, C. V. (2013). Pollen grain morphology of Fabaceae in the Special Protection Area (SPA) Pau-de-Fruta, Diamantina, Minas Gerais, Brazil. Anais da Academia Brasileira de Ciencias, 85(4), 1329-1344. https://doi.org/10.1590/0001-3765201380511

Erdtman, G. (1969). Handbook of palynology - an introduction to the study of pollen grains and spores. Munksgaard.

Graham, P. H., \& Ranalli, P. (1997). Common bean (Phaseolus vulgaris L.). Field Crops Research, 53(13), 131-146. https://doi.org/10.1016/S03784290(97)00112-3

Heslop-Harrison,J.(1972). Sexuality of angiosperms. In F. C. Steward (Ed.), Plant physiology: a treatise (pp. 134-289). Academic Press.

López, J., Rodríguez-Riaño, T., Ortega-Olivencia, A., Devesa, J. A., \& Ruiz, T. (1999). Pollination mechanisms and pollen-ovule ratios in some Genisteae (Fabaceae) from Southwestern Europe. Plant Systematics and Evolution, 216(1-2), 23-47. https://doi.org/10.1007/bf00985099

Nakano, Y., \& Asada, K. (1981). Hydrogen peroxide is scavenged by ascorbate-specific peroxidase in spinach chloroplasts. Plant and Cell Physiology, 22(5), 867-880. https://doi.org/10.1093/ oxfordjournals.pcp.a076232

Radice, S., Ontivero, M., Giordani, E., \& Bellini, E. (2008). Anatomical differences on development of fertile and sterile pollen grains of Prunus salicina Lindl. Plant Systematics and Evolution, 273, 63-69. https://doi.org/10.1007/s00606-0080011-5

Schrire, B. D. (1989). A multidisciplinary approach to pollination biology in the Leguminosae. In C. H. Stirton \& J. L. Zarucchi (Eds.), Advances in legume biology. Monographs in Systematic 
Botany from the Missouri Botanical Garden. Vol. 29 (pp. 183-242). Missouri Botanical Garden Press.

Stirton, C. H. (1981). Petal sculpturing in papilionoid legumes. In R. P. Polhimm RM (Ed.), Advances in legume systematics (pp. 771-788). Royal Botanical Gardens Kew.
Suzuki, K., Takeda, H., Tsukaguchi, T., \& Egawa, Y. (2001). Ultrastructural study on degeneration of tapetum in anther of snap bean (Phaseolus vulgaris L.) under heat stress. Sexual Plant Reproduction, 13(6), 293-299. https://doi. org/10.1007/s004970100071

\title{
Порівняльна будова репродуктивних структур різних генотипів Phaseolus vulgaris, вирощених в однакових умовах м. Мерсін, Туреччина
}

\author{
Ділек Текдаль ${ }^{1, *}$, Шаліма Шавуті Кан ${ }^{2}$, Аслі Кючюкрецеп ${ }^{3}$
}

1 Відділ біотехнології, факультет науки та літератури, Мерсинський університет, Мерсін, 33110, Туречина; * dilektekdal@mersin.edu.tr

2 Відділ фізіології, факультет медицини, Істанбульський університет, Істанбул, 34452, Туречина

${ }^{3}$ Відділ біотехнології, інститут науки, Мерсинський університет, Мерсін, 33110, Туречина

Квасоля звичайна (Phaseolus vulgaris) - це рослина з двостатевими квітками, які піддаються самозапиленню. Це важлива комерційна культура, що $є$ однією з найцінніших для спожитку серед бобових Туреччини. При цьому, генетичні варіації спостерігаються як в межах так і між окремими популяціями цих рослин. Ці варіації можуть впливати на будову органів рослин, включаючи репродуктивні структури. Відповідно, різниця у формі і розмірі репродуктивних структур може обумовлювати різний ступень якості запліднення. В цій праці представлено результати дослідження морфології деяких репродуктивних структур чотирьох генотипів квасолі звичайної (Akman, Bitlis 117, Göksun та Karacaşehir). Рослини вирощували при $21 / 16^{\circ} \mathrm{C}$ (день/ніч) і 12-годинному фотоперіоді у теплицях м. Мерсін, Туреччина. Основна увага була приділена морфології пилку, однак деякі фактори, що визначають успішність запліднення (зокрема, будова бобів і набори насінин) було проаналізовано також. Було полічено кількість бобів та насінини у кожному з них. Для дослідження морфології пилку, було відібрано бутони усіх чотирьох генотипів однакового етапу розвитку і проаналізовано з використанням сканувального електронного мікроскопу. Зазвичай різні види відрізняються за розміром пилкових зерен, орнаментацією екзини і типом ендоапертури. Також важливо звертати увагу на розподіл пилку у запилених квітках, адже це може впливати на результативність запліднення. Однак, у всіх вивчених генотипів архітектура пилкової стінки була значною мірою подібною. Не зважаючи на загальну морфологічну подібність, спостерігались відмінності у життєздатності пилку, а також кількості бобів та насінин у досліджених генотипів. Хоча у генотипу Akman були найбільші квітки, генотип Karacaşehir виявився найбільш продуктивним. Отримані результати можуть бути корисними для дослідників, які вивчають розмноження бобових та варіабельність генотипів квасолі. 